\section{Central adverbial clauses and the derivation of subject-initial V2}

Liliane Haegeman

DiaLing (Ghent University)

\section{Introduction and background}

This chapter explores aspects of the syntax of what have been referred to as V2 transgressions (Catasso 2015), i.e. patterns in V2 languages in which the finite verb is linearly preceded by two constituents rather than by the expected one constituent. The focus is on those cases in which the initial constituent in the V2 transgression is an adverbial clause. The data are drawn from Dutch and from the West Flemish dialect; it is expected that the core observations carry over to German (see a.o. Reis 1997 and d'Avis 2004, for German).

In the literature, it has been proposed that where V2 languages seem to allow for V2 transgressions, the resulting V3 patterns can be brought in line with the V2 generalization on the assumption that the initial constituent which effectively leads to the V3 order is 'main clause external' (Broekhuis and Corver 2016: 1679-1733), 'extra cyclic' (Zwart 2005) or 'extra sentential' (Astruc-Aguilera 2005). By this reasoning, the combination of the main clause externa constituent and the V2 root clause would be one that is in the domain of discourse syntax an should, at first sight, not be sensitive to the internal narrow syntax properties of its components. Being main clalgext, no be se clo be perticin to partipa clo which it precedes and cobirs constituent, this adverbial clause would be expected to be of the non-integrated type (see below for more details). Conversely, all wings being equal, it is expected that adverbial clauses that have to be senantically integrated with their associated clause would not be able to constitute the initial, i.e. main clause external, constituent in a 33 configuration. For instance, being in a main claus external position, a temporal/conditional adverbial clause which is in the extra sentential positio would not be able to value the temporal/modal coordinates of the associated matrix domain.

At first sight these predictions may seem correct. In Standard Dutch (1a), a V3 pattern results from the combination of a temporal adverbial clause with a fully-fledged V2 root clause. This entails that the adverbial clause must be occupying a main clause external position. The example is ungrammatical. In (1b), the initial adverbial clause is a relevance conditional, which has the hallmarks of being less integrated with the associated domain (see Section 1.1) and this clause is unproblematic in the same configuration:

(1)

$$
\begin{aligned}
& \begin{array}{clll}
*[\text { Adj-Xp Als } & \text { mijn tekst } & \text { morgen } & \text { klaar is, } \\
\text { if } & \text { my text } & \text { tomorrow } & \text { reary }
\end{array} \\
& \text { tomorrow ready is, } \\
& \begin{array}{lllll}
\text { CP } & {[\mathrm{ik}} & \text { zal } & \text { je } & \text { hem opsture } \\
& \text { I } & \text { will } & \text { you } & \text { him send }
\end{array} \\
& \text { 'If my text is ready tomorrow, I will send it to you. }{ }^{3} \\
& \text { b. [Adj-XP Als je honger hebt,] }
\end{aligned}
$$

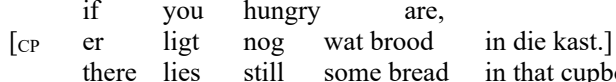

$$
\begin{aligned}
& \text { 'If you are hungry, there is bread in that cupboard.' }
\end{aligned}
$$

However, the prediction above is not always confirmed. First, the degradation of a V3 pattern with an initial temporal adverbial clause like that illustrated in (1a) is not general: it is restricted to the V3 combination of this type of adverbial clause with a subject-initial V2 clause with information structurally undistinguished subject. Data such as (13) in Section 2.3.1. show that non subjectinitial V2 clauses can in fact combine with a temporal adverbial clause leading to acceptable V3 patterns. In addition, while (1a) is unacceptable in Standard Dutch, its counterpart in West Flemish, which is a bona fide V2 language, is grammatical.

Based on the cartographic analysis for main clause external constituents developed in Greco and Haegeman (2016) and Haegeman and Greco (2018), the present chapter will account for the restrictions on V3 patterns with a temporal/conditional adverbial clause in first position. Among other things, the data discussed here will provide new empirical support for an asymmetric analysis of V2.

Before dealing with the V2 transgressions I will first provide an overview of a typology of adverbial clauses based on English data, which I will then use in the subsequent discussion of Dutch.

1.1. A typology of adverbial clauses: central vs. peripheral

There is by and large a consensus in the literature that what are commonly called 'adverbial clauses' include a wide range of relatively disparate types of modifying clauses which are distinguished - among other things - by the degree of syntactic and semantic integration into the matrix clause. The difference between adverbial clauses is aptly illustrated by examples like (2), in which two if-clauses appear in initial position.

(2) a. If you fail the entrance exam, you will have a chance to retake it

b. If you are hungry, I left some biscuits in the cupboard.

In (2a) the if-clause is closely integrated with the associated clause: it encodes a condition for the realisation of the main clause event. In ( $2 b$ ), the if clause is a relevance conditional (Haegeman 1991,2009), sometimes referred to as biscuit conditional in the literature (Austin 1956), which encodes a felicity condition for the following utterance. In (2b) the conditional clause is not closely integrated with the associated clause: the condition 'if you are hungry' does not impact on the truth conditions of the associated clause, which is true independently of whether the interlocutor is hungry. In earlier work (Haegeman 1991, 2009) I have labelled the 'integrated' adverbial clauses 'central' adverbial clauses, and will use this term here (but see Frey and Haegeman (in prep) for a nuanced view). Because of the lesser syntactic and semantic integration of the if-clause in ( $2 b$ ), I introduced the label 'peripheral adverbial clause' to refer to the type of adverbial clauses whose function is that of modifying the illocution and structuring the discourse.

Haegeman $(1991,2008)$ proposes to treat peripheral adverbial clauses as 'orphans', i.e. constituents that are not syntactically integrated with the clause they modify. However, note that even a relevance conditional such as that in (2b) remains to some extent integrated with the clause that it associates with. Support for this comes from the observation that when the associated clause is introduced by a coordinating conjunction, this conjunction must precede the if-clause, as shown in (3a), and bears on the combination of the if-clause and the clause it modifies. The conjunction cannot simply be associated only with the modified main clause (3b). (See d'Avis 2004: 147 for this argument.)

(3) a. And, [if you're hungry,] there are biscuits in the cupboard.

b. *[If you're hungry, ] ... and there are biscuits in the cupboard.

That adverbial clauses may be more or less integrated with the clause they modify is well known from the literature and the variation in the degree of integration has received attention. In terms 
of Huddleston's (1984: 379-80) terminology, for instance, peripheral adverbial clauses, while subordinated to the clause they are associated with, are not 'embedded'. Importantly for our (the degree of integration be represented syntactically (Huddleston 1984: 379-80). There is a considerable literature on the typology of adverbial clauses which I will not review here. For more discussion see, among other, the following: van der Auwera (1986), Haspelmath and König (1998), König and van der Auwera (1988), Reis (1997), d'Avis (2004), Reis and Wöllstein (2010).

In the next sections I briefly show that central and peripheral adverbial clauses pattern differently both in terms of their external syntax and in terms of their internal syntax. I will not go into these points in much detail but refer to the literature cited and for my own take on the data, which I will be adopting here, I refer to my own published work (Haegeman 1991, 2002, 2003, 2004, 2006, 2009 and 2012)

1.2. External syntax of adverbial clauses

Haegeman (2012) proposes that central adverbial clauses be merged at a TP-internal level of the clause, while peripheral adverbial clauses be merged outside the CP layer. Peripheral adverbial clauses are thus in what could be labelled a main clause external position (Broekhuis and Corver 2016: 1679-1733).

(4) a.

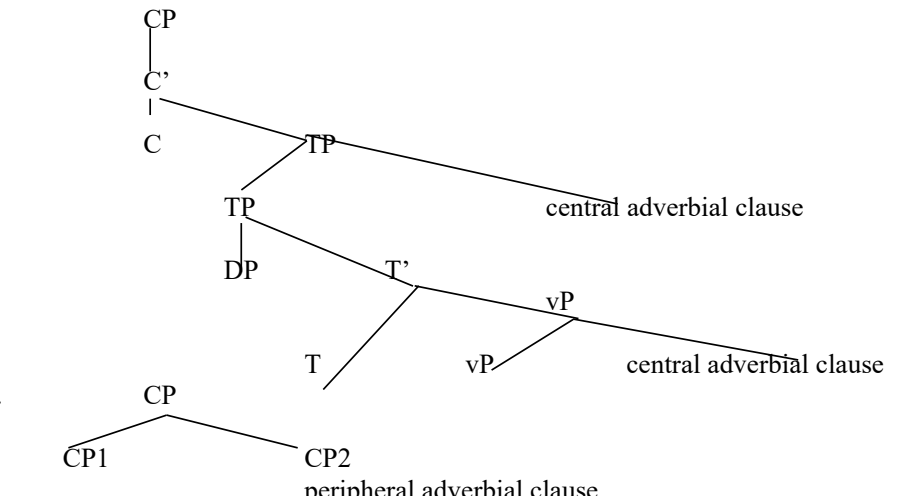

The proposal is that central adverbial clauses are fully syntactically (and hence semantically) integrated in the clause they modify, and that peripheral adverbial clauses are integrated to a lesser degree. Evidence for the lower level of integration has been provided in the literature. For instance, central adverbial clauses can be shown to be within the scope of matrix operators, while peripheral adverbial clauses remain outside the scope of the same operators. For instance, (5) peripheral adverbial clauses remain outside the scope of the same operators. For instance, $(5)$ clefted (Haegeman 2006, 2012)

(5) a. It is only if you fail the entrance exam that you will have a chance to do a retake. b. $\quad$ It is only if you are hungry that I left some biscuits in the cupboard.

Similarly, the central conditional clause in (2a) can be used in reply to a wh question, while this is not possible for the relevance conditional in $(2 b)$
(6) a. A: When will I have a chance to do a retake?

B: If you fail the entrance exam.

b. A: When did you leave biscuits in the cupboard?

B: If you are hungry.

For additional evidence see Haegeman (1991, 2002, 2003, 2004, 2006, 2009, 2012).

1.3. Organisation of the chapter

In the present chapter, I explore the implications of the hypotheses concerning the degree of syntactic integration of adverbial clauses as outlined above for the syntax of verb second clauses. The chapter is organised as follows. Section 2 shows that, contrary to expectation, even in Standard Dutch, central adverbial clauses, which should by hypothesis be structurally integrated, do occur as the initial 'main clause external' constituents in a subset of V3 configurations and it will be argued that the availability of these configurations depends on the presence or absence of inversion in the root clause as well as on the information structural nature of the subject of the root clause. Section 3 addresses the analysis of 'unintegrated' main clause external constituents in a V3 configuration. Section 4 returns to the 'problematic' data uncovered in Section 2, i.e. central adverbial clauses which occupy what looks like the 'unintegrated' main clause externa position in a V3 configuration. Section 5 analyses the patterns in terms of the syntactic analysis

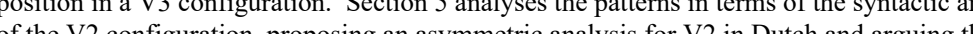
po

\section{Initial adverbial clauses and V2: the case of Dutch}

2.1. Verb Second

Dutch is a V2 language: in root declaratives, the finite verb is preceded by just one constituent. In (7a), the initial constituent is a direct object; in (7b), it is the verbal part of the predicate; in (7c), it is an adjectival predicate. For each example, having two constituents to the left of the finite verb leads to ungrammaticality, as shown in the primed examples. In all cases, the definite subject nominal will immediately follow the finite verb.

(7) a. Dienen oto ee Valère gisteren voor zen dochter gekocht that car has Valère yesterday for his daughter bought

a'. *Dienen oto Valère ee gisteren voor zen dochter gekocht.

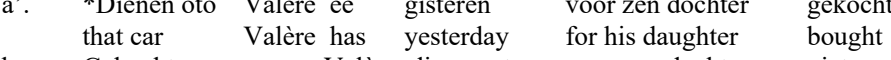

b. Gekocht ee Valère dienen oto voor zen dochter niet.

bought has Valère that car for his daughter not
*Gekocht Valère ee dienen oto

"Gekocht Valère ee dienen oto voor zen dochter niet.

$\begin{array}{llll}\text { c. Styf diere } & \text { is den wyn tegenwoordig niet. }\end{array}$

, very expensive is the wine nowadays not

*Styf diere den wyn is tegenwoordig niet

In terms of the structural representation of the V2 clause I will provisionally adopt the format in (8), with the finite verb moving to $\mathrm{C}$ and the initial constituent moving to SpecCP. I assume that 
the $\mathrm{CP}$ level is the level at which illocutionary force is encoded. Some revisions will be discussed in Section 5 .

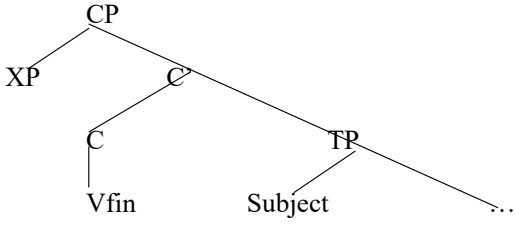

2.2. Peripheral adverbial clauses in V2 transgressions in Dutch

Peripheral adverbial clauses do not impact on the truth conditions of the associated proposition but instead provide discourse-related specifications concerning, for instance, felicity conditions of the speech act they associate with or processing restrictions on the associated matrix clause. Some examples are given in (9) with an initial conditional clause. The event or state of affairs encoded in the matrix CP is not conditional on the realisation of the state of affairs encoded in the peripheral conditional clause (labelled Adj-XP): the main speech act (assertion, question) in the $\mathrm{V} 2$ root clause remains valid regardless of Adj-XP. I assume that peripheral adverbial clauses combine with a root $\mathrm{CP}$, i.c. a root $\mathrm{V} 2$ clause: 4

(9) a. [Adj-XP Als je honger hebt, ] [cP in die kast ligt er nog wat brood.] $\begin{array}{llll}\text { [Adj-XP Als je honger hebt, }]\left[\begin{array}{ll}\mathrm{CP} \text { in } \\ \text { if you hungry are, in }\end{array} \text { in }\right. & \begin{array}{l}\text { die kast ligt } \\ \text { that cupboard lies }\end{array} \text { there still some bread }\end{array}$ if you hungry are,
'If you are hungry, there is some bread in that cupboard.'

b. [Adj-XP Als het je interesseert,

$\begin{array}{llll}\text { [CP in PARIJS zal } & \text { er } & \text { ook een vacature zijn.] }\end{array}$

in Paris will there also a vacancy be

'If you are interested, in Paris there is also a vacancy.'

c. [Adj-XP Als je abstract toch klaar is, ]

[CP waarom heb je het nog niet opgestuurd? why have you it PART not sent

'If - as you say - your abstract is ready, why haven't you sent it already?

d. [Adj-XP Als je honger hebt,

[CP er ligt nog wat brood in die kast.]

there lies still some bread in that cupboard

'If you are hungry, there is bread in that cupboard.'

The presence of the initial peripheral adverbial clauses in (9) leads to a V3 order. These patterns remain compatible with the general assumptions on the derivation of V2: the peripheral adverbial clauses in (9) are non-integrated, they are 'main clause external constituents' in the sense of Broekhuis and Corver (2016), and hence they do not 'count' for V2. CP encodes speech act properties, and the peripheral adverbial clause is added 'onto' that, i.e. it does not itself encode the speech act of the matrix clause. (10) is a schematic representation:
(10)

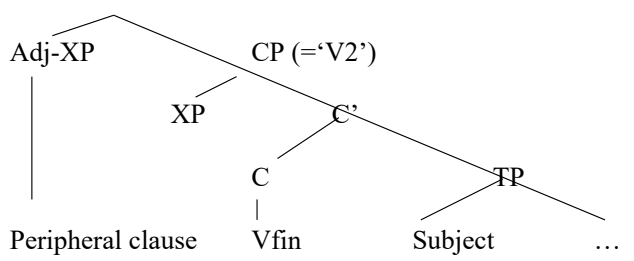

As already pointed out: peripheral adverbial clauses are not totally independent from the associated clause. As was the case for the English relevance conditional ( $2 b$ ), Dutch periphera adverbial clauses follow the coordinating conjunction (11a-d) and cannot precede it (11e-f):

(11) a. maar/en als je honger hebt,

but/and if you hungry are,

in die kast ligt er nog wat brood.

'And/but if you are hungry, there is some bread in that cupboard.'

b. maar/en als het je interesseert,

but/and if it you interests,

in PARIJS zal er ook een vacature zijn.

in Paris will there also a vacancy be

'but/and if you are interested, in Paris there is also a vacancy.'

c. maar/en als je abstract toch klaar is,

$\begin{array}{llll}\text { wat/and hem lo je het nog niet opgestuurd? } & \end{array}$

$\begin{array}{lllll}\text { waarom } & \text { heb je } & \text { het } & \text { nog } & \text { niet opgest } \\ \text { why } & \text { have } & \text { you it } & \text { PART } & \text { not sent }\end{array}$

'and/but if - as you say - your abstract is ready, why haven't you sent it already?'

d. maar/en als je honger hebt,

but/and if you hunger have,

er ligt nog wat brood in die kast.

there lies still some bread in that cupboard

'but/and if you are hungry, there is bread in that cupboard.'

e. Als je honger hebt,

maar/en in die kast ligt er nog wat brood.

but/and in that cupboard lies there still some bread

f. *?Als het je interesseert

if it you interests

maar/en in PARIS zal er ook een vacature zijn.

$\begin{array}{lllllll}\text { maar/en } & \text { in PARIS } & \text { zal } & \text { er } & \text { ook } & \text { een vacature } & \text { zijn } \\ \text { but/and } & \text { in Paris } & \text { will } & \text { there } & \text { also } & \text { a vacancy } & \text { be }\end{array}$

toch klaar is,

if your abstract PART ready is,

heb je het nog niet opgestuurd?

have you it PART not sent

h. *Als je honger hebt,

if you hunger have,

maar/en er ligt nog wat brood in die kast.

but/and there lies still some bread in that cupboar 
In contrast with peripheral adverbial clauses, central adverbial clauses modify the truth conditions of the associated clause. This implies that central adverbial clauses must be integrated in the main clause and the prediction would be that central adverbial clauses cannot constitute 'main clause external' constituent. Dutch (1a), repeated as (12a), is correctly predicted to be ungrammatical, because the initial conditional clause is 'central', it encodes a condition on the realisation of the main proposition and should thus be semantically and syntactically integrated. The grammatical variant is $(12 \mathrm{~b})$.

$$
\begin{aligned}
& \text { a. } \quad * \text { Adj-XP Als mijn tekst } \\
& \begin{array}{llll} 
& \text { if my text } & \text { momorrow ready is, } \\
\text { CP } & {[\mathrm{ik}]} & \text { [zal] je } & \text { hem opsturen.] }
\end{array} \\
& \text { I will you him send } \\
& \text { b. 'If my text is ready tomorrow, I will send it to you.' } \\
& \begin{array}{llllll}
\text { [CP [Als mijn } & \text { tekst } & \text { morgen } & \text { klaar is, }] \\
\text { if my } & \text { text } & \text { tomorrow } & \text { ready } & \text { is, } \\
\text { [C zal] } & \text { [TP } & \text { ik je } & \text { hem } & \text { opsturen.] }] \\
\text { will } & & \text { I } & \text { you } & \text { him } & \text { send }
\end{array}
\end{aligned}
$$

'If my text is ready tomorrow, I will send it to you.'

A straightforward account for the ungrammaticality of (1/12a) might seem to be that it violates the V2 condition: the finite verb zal ('will') is preceded by two constituents, the subject $i k$ ('I') and the adverbial clause als mijn tekst morgen klaar is ('if my text is ready tomorrow').

However, it is far from clear that this is the way to approach this example, and this for at least two reasons. (i) As shown in Section 5, the West Flemish (from now on WF) equivalent of (12a) is acceptable, while WF is also a bona fide V2 language. (ii) The second obstacle to a V2 is acceptable, while WF is also a bona fide V2 language. (ii) The second obstacle to a V2 account for (12a) is that Standard Dutch does allow for $\mathrm{V}$ transgressions in which the initial constituent in the V3 pattern is a central adverbial clause which modifies the temporal values of
the associated TP, these will be discussed in the next section. If such transgressions are possible, the associated TP, these will be discussed in the next section. If such transgressions are possib then the unacceptability of (12a) is by no means accounted for simply in terms of the V2 restriction.

2.3. Central adverbial clauses in V2 transgressions in Dutch

2.3.1. Non subject-initial V2

In linear terms, the examples in (13) instantiate $\mathrm{V} 3$ patterns but in contrast with the examples in (9) and relevant for the discussion here, the initial adverbial clause is central: it modifies the temporal/modal coordinates of the matrix clause. Nevertheless, these examples are acceptable.

(13) a. [Adj-XP Als ik klaar ben met de handout, if I ready am with the handout, $\begin{array}{llllll}\text { if I ready am with } & \text { the handout, } & \\ \text { [CP } & \text { [aan wie] } & \text { moet } & \text { ik } & \text { hem } & \text { tonen?] } \\ \text { to whom } & \text { should } & \text { I } & \text { him } & \text { show }\end{array}$ 'If my handout is ready, to whom should I show it?'

b. [Adj-XP Als er morgen een probleem is,

[CP [MIJ] moet je niet bellen]

$$
\text { ME must you not call }
$$

'If there is a problem tomorrow, don't call ME.
While the V3 patterns in (13) are accepted by most speakers of Standard Dutch (from now on abbreviated as StD) ${ }^{5}$, example (12a) above, which seems to instantiate the same pattern, is not grammatical.

For a subset of StD speakers, the V2 transgressions in (13) are degraded; these speakers systematically require the insertion of an appropriate resumptive adverbial - dan ('then') - in the matrix clause, as shown in (14):6

$$
\begin{aligned}
& \begin{array}{clrl}
\text { [Adj-XP Als ik klaar ben met de handout,] } \\
\text { if I }
\end{array} \\
& \text { [CP [aan wie] ready am with the handout } \\
& \text { to whom must I him then show } \\
& \text { If my handout is read, to whom should I show it? } \\
& \text { b. [Adj-XP Als er morgen en probleem is, } \\
& \text { [CP [MIJ] moet je \%dan niet bellen.] } \\
& \text { me must you then notcall }
\end{aligned}
$$$$
\text { 'If there is a problem tomorrow, then don't call me.' }
$$

An important proviso here is the following: even for StD speakers who only accept the version An impor ('then') in (14), in

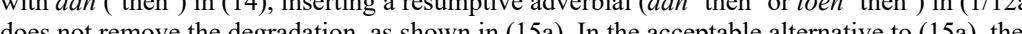
resumptive adverbial dan would have to occupy the initial position in the adverbial resumptive $\mathrm{V} 3$ pattern, as shown in $(15 \mathrm{~b})$

(15)

$$
\begin{aligned}
& \text { *[Als mijn tekst morgen klaar is, } \\
& \text { if my text tomorrow ready is } \\
& \text { [ik] zal je hem dan opsturen. } \\
& \text { 'If my text is ready tomorrow, I will send it to you.' } \\
& \text { b. [Als mijn tekst morgen klaar is, } \\
& \text { if my text tomorrow ready is } \\
& \text { dan zal ik je hem opsturen. } \\
& \text { then will I you him send } \\
& \text { 'If my text is ready tomorrow, I will send it to you.' }
\end{aligned}
$$

The generalization that emerges from the data presented here is that the acceptability of a central adverbial clause as the initial constituent in a V3 pattern depends on the specific instantiation of the $\mathrm{V} 2$ pattern in the $\mathrm{CP}$ which it precedes and combines with:

(i) a V2 transgression consisting of a central adverbial clause combined with a subject-initial V2 root clause (Mikkelsen 2015) is unacceptable, as shown in $(1 \mathrm{a}) /(12 \mathrm{a}) /(15 \mathrm{a})$;

(ii) a V2 transgression consisting of a central adverbial clause combined with a non subject-initial V2 root clause is acceptable (13) (with the proviso of dan-insertion for a subset of speaker);

2.3.2. Subject-initial V2

The descriptive generalization sketched in the conclusion of the preceding section is not quite adequate in that not all combinations of central adverbial clauses and subject-initial V2 clauses 
lead to unacceptable V3 patterns: the acceptability of such V3 patterns also depends on the nature of the subject. As shown by (16), the V3 combination of a central adverbial clause with a subject-initial V2 root clause whose subject is informationally distinguished (in the sense of Mikkelsen 2015) is acceptable. In (16a), the central adverbial clause precedes a subject-initial V2 clause with a focussed subject PIET, and this example is accepted by my StD informants. Similarly, the subject in (16b) is a wh-subject and the V3 configuration is accepted.

(16) a

$$
\begin{aligned}
& \text { a. }[\text { Als er morgen een probleem is, } \\
& \text { if there tomorrow a problem is } \\
& \text { [PIET] zal ons niet helpen. } \\
& \text { Piet will us not help } \\
& \text { 'If there is a problem tomorrow, Piet won't help us.' } \\
& \text { b. [Als er morgen een probleem is,] } \\
& \text { if there tomorrow a problem is } \\
& \text { [wie] zal ons helpen?' } \\
& \text { who will us help } \\
& \text { 'If there is a problem tomorrow, who will help us?' }
\end{aligned}
$$

Informants who found (13) degraded without the resumptive adverbial dan, also found (16a) degraded; for those speakers, insertion of dan ('then') again rendered the example acceptable (17a). All StD informants accepted (16b). In an informal survey with native speakers, speakers who found (16a) doraded noted only a slight degratat (a score 6/7) for (16b), and expressed a slight preference for (17b) with resumptive dan (a score of $7 / 7$ ).

(17)

$$
\begin{aligned}
& \begin{array}{lll}
\text { [Als er } & \text { morgen } & \text { een probleem is, } \\
\text { if there } & \text { tomorrow }
\end{array} \\
& \text { if there tomorrow a problem is } \\
& \text { PIET] zal ons dan niet helpen. } \\
& \text { Piet will us then not help } \\
& \text { 'If there is a problem tomorrow, PIET won't help us.' } \\
& \text { b. }[\mathrm{Als} \text { er morgen een probleem is, } \\
& \text { if there tomorrow a problem is } \\
& \text { [wie] zal ons dan helpen? } \\
& \text { who will us then help } \\
& \text { 'If there is a problem tomorrow, who will help us?' }
\end{aligned}
$$

2.3.3. V2 transgressions in Standard Dutch

On the basis of the data discussed in Section 2.3.2, I revise the descriptive generalizations as follows:

(i) a V2 transgression consisting of a central adverbial clause combined with a subject-initial V2 root clause in which the subject is information structurally undistinguished (Mikkelsen 2015) is unacceptable;

(ii) a V2 transgression consisting of a central adverbial clause combined with a non subjectinitial V2 root clause is acceptable (with the proviso of dan-insertion for a subset of speaker);

(iii) a V2 transgression consisting of a central adverbial clause combined with a subject-initial V2 root clause in which the subject is information structurally distinguished (Mikkelsen 2015) is acceptable.
The descriptive generalizations are summarised in Table 1: the relevant pattern is summarized in the first column, the StD judgement is given in the second column, the third column provides a reference to the relevant text-example.

Table 1: V2 transgressions in StD with central adverbial clause

\begin{tabular}{|lll|l|l|}
\hline V2 transgression & & StD & Example number \\
\hline Adj-XP & undistinguished Subj & Vfin & $*$ & $(12 \mathrm{a})$ \\
\hline Adj-XP & distinguished Subj & Vfin & $\sqrt{ }$ & $(16)-(17)$ \\
\hline Adj-XP & non-Subj $\left[+{ }_{[+\mathrm{wH}]}\right.$ & Vfin & $\sqrt{ }$ & $(13)-(14)$ \\
\hline
\end{tabular}

Observe that the nature of the $\mathrm{V} 2$ pattern or the nature of the subject do not affect the status of the V2 transgressions with peripheral adverbial clauses, as summarized in Table 2.

Table 2: V2 transgressions in StD with peripheral adverbial clauses

\begin{tabular}{|lll|l|l|}
\hline \multicolumn{2}{|l|}{ V2 transgression } & & StD & Example number \\
\hline Adj-XP & Subj & Vfin & $\sqrt{ }$ & $(9 \mathrm{~d})$ \\
\hline Adj-XP & wh-phrase & Vfin & $\sqrt{ }$ & $(9 \mathrm{c})$ \\
\hline Adj-XP & non-Subj & Vfin & $\sqrt{ }$ & $(9 \mathrm{a}, \mathrm{b})$ \\
\hline
\end{tabular}

From this survey, the following question emerges: if $\mathrm{V} 2$ transgressions are acceptable with centra adverbial clauses in (13) and (16), why are they not acceptable in (12a)? Put differently: If, despite its status as main clause external, the initial central adverbial clause in (13) and in (16) can modify the temporal/modal values of the associated V2 clause in what looks like a V3 pattern, why can it not do so in (12a)?

2.4. Irrelevance conditionals (d'Avis 2004)

Observe that while combining a conditional clause which modifies the modal coordinates of the associated subject-initial matrix clause leads to unacceptability in (12a), repeated in (18a), in the same context, what might appear to be a closely similar irrelevance conditional (in the sense of d'Avis 2004) does not lead to a degradation, as shown by the acceptability of (18b). This observation was made in d'Avis (2004):

$$
\begin{aligned}
& \begin{array}{clll}
\text { *[Als mijn tekst morgen } & \text { klaar is, } \\
\text { if my text } & \text { tomorrow } & \text { ready is }
\end{array} \\
& \text { if my text tomorrow ready } \\
& \text { [ik] } \mathrm{zal} \text { je hem opsturen. } \\
& \text { will you him send } \\
& \text { 'If my text is ready tomorrow, I will send it to you.' } \\
& \text { b. [Of mijn tekst morgen klaar is of niet, } \\
& \begin{array}{lllll}
\text { if } & \text { my text } & \multicolumn{2}{c}{\text { tomorrow rew }} \\
\text { [ik] } & \text { zal } & \text { je } & \text { hem } & \text { opsturen. } \\
\text { I } & \text { will } & \text { you } & \text { him } & \text { send }
\end{array} \\
& \text { 'Whether my text is ready or not tomorrow, I will send it to you.' }
\end{aligned}
$$

Irrelevance conditionals differ from central conditional clauses in that "the truth of a set of propositions that can be derived from the I[rrelevance] C[onditional] is irrelevant for the truth of the proposition of the M[atrix] C[lause]." (d'Avis 2004: 142)

2.5. Research question 
The survey of the data provided above leads to several questions:

(i) Why can central adverbial clauses appear as the main clause external constituent in V3 patterns at all?

(ii) Why can central adverbial clauses appear as the main clause external constituent in V3 patterns in only a subset of $\mathrm{V} 2$ transgressions?

(iii) Why and how does the difference between subject-initial and non subject-initial V2 clauses bear on the acceptability of V2 transgressions with a central adverbial clause?

(iv) Why and how does the information structural status of the subject bear on V2 transgressions with central adverbial clauses?

To address these issues, I first summarize a proposal elaborated in Greco and Haegeman (2016) and in Haegeman and Greco (2018) for the syntax and interpretation of main clause external constituents.

\section{Peripheral adverbial clauses as main clause external constituents}

There is a consensus that the initial peripheral adjunct in the licit examples in (9) does not violate the V2 constraint, because it is 'outside' the syntax. There are numerous proposals in the literature for representing this 'external' status: (19a-d) offers just some examples. Auer (1996) refers to a 'Vor-vorfeld' (pre-frontfield) in contrast to the Vorfeld (front field) (19a); Skorup (1975) uses the

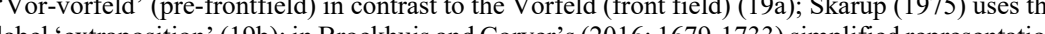
' (19); in Brocen my own work (cf. (4))

(19) a. [Vor-Vorfeld

$$
\begin{aligned}
& \text {... } \quad V_{\text {fin }} \text { ]] (Auer 1996) } \\
& \text { [Preverbal zone }{ }^{8} \text { [VERBAL zone] [Postverbal zone] } \\
& \text { c. [main clause } \\
& \text { (Skårup 1975: 179) }
\end{aligned}
$$

d. [CP Peripheral adjunct $\left[\begin{array}{cc}\text { (BP ... } & \text { [Troekhuis and Corver 2016: 1679-1733) } \\ \text { (HPaegeman 2004, 2006, 2012) }\end{array}\right.$

In what follows I outline the approach developed in Haegeman and Greco (2018), which explores an insight due to Auer (1996) which brings to the fore the framing function of the VorVorfeld. Haegeman and Greco (2018) propose that the combination of the main clause external constituent with $\mathrm{CP}$ leads to a novel projection, their 'FrameP'.

(19) e.

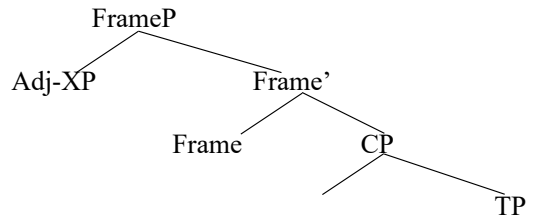

The following are the main ingredients of the proposal:

(i) The projection FrameP results from the merger of the main clause external adjunct (Adj-XP) and a constituent labelled ForceP in Haegeman and Greco (2018). Haegeman and Greco (2018) borrow the label ForceP from the cartographic tradition (Rizzi 1997)
ForceP is the constituent layer that encodes illocutionary force. For our purposes, it can be taken to correspond to the roo v2 clause. For ease of exposition, Had V2 cla should bear in mind hat in (19e) CP en

(ii) For the interpretation of the FrameP configuration, Greco and Haegeman (2016) and Haegeman and Greco (2018) propose that the initial adjunct XP-Adj in SpecFran introduces an entity (or a set of entities) in the discourse which will serve as the context with respect to which the proposition expressed by the associated V2 clause is interpreted as relevant.

(iii)For Haegeman and Greco (2018), the merger of the main clause external constituen (here Adj-XP) with CP is a discourse structuring ('framing') operation. It creates a discourse entity, FrameP. The specifier of FrameP is not syntactically integrated with the associated clause.

Haegeman and Greco's FrameP in (19e) corresponds to several proposals in the literature, including, among others, Banfield's (1982) E-node, Cinque's (2008) HP (also adopted in Giorgi 2014, Frascarelli 2016), Koster's (2000) :P ('colonP'), de Vries's (2009) ParP (also adopted in Griffiths and De Vries's (2013)). In this respect, their (19e) differs from those who take the

relevant V3 transgression to be a further extension of the "Rizzian" left periphery (cf. Holmberg 2015).

The two constituents of FrameP (19e) will be construed relatively independently: in this case, the denotation of Adj-XP does not impact on the truth conditions of the V2 root clause, CP. For instance, in (20a) the peripheral conditional clause modifies the speech act, which is presented as relevant 'if the hearer must know'; the conditional clause must be construed as relevant with respect to the root clause speech act (CP1), and it cannot be construed as a condition on the embedded speech act reported under the verb of saying (CP2). The choice of the subject pronouns in the conditional clause reflects this: in (20a) the conditional clause targets the addressee of the root speech act, 'you'. The intended addressee of the conditional clause in (20c) would be that of the embedded speech act, 'I', but this is infelicitous. (20b) represents the acceptable reading; (20d) schematizes what would be the illicit reading.

(20) a. [FrameP [Als je het moet weten,

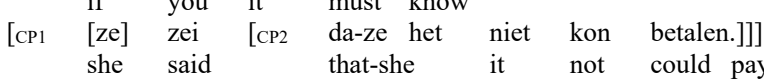

'If you must know, she told me she couldn't pay for it.'

b. [FrameP Adj-XP [Frame] [CP1 ... [CP2 ...]]]

(1)

c. * $\quad$ FrameP $[$ Als ik het moet weten,

[CP1 [ze] zei me [CP2 da-ze het niet kon betalen.]]]

d. $\quad *[$ FrameP Adj-XP $[$ Frame $][\mathrm{CP} 1 \ldots \quad[\mathrm{CP} 2 \ldots]]]$ $\vdots$

Put differently, not being syntactically integrated with $\mathrm{CP}$, the initial main clause external speech act modifier in SpecFrameP cannot be construed CP-internally at the level of the embedded 
domain. To capture this restriction, Haegeman and Greco (2018) postulate a strict locality condition on the interpretation of FrameP. While initially formulated on the basis of the interpretation of peripheral adverbial clauses in the specifier of FrameP, they then postulate that the locality condition be generalized and that its scope also includes central adverbial clauses in the locality

\section{Central adverbial clauses as main clause external constituents}

4.1. Inverted $V 2$ and the derivation of temporal readings

Interpretively, a central adverbial clause functions as a restrictor for the evaluation conditions of the proposition expressed in the main clause. ${ }^{11}$ A priori, one would not expect a central adverbia clause to be able to be merged as a main clause external constituent in SpecFrameP. By Haegeman and Greco's generalized locality condition on the interpretation of FrameP (cf. (20b)), a central adverbial clause in SpecFrameP can only provide a value for a temporal or modal variable in the matrix clause provided it has a strictly local relation with the temporal or modal value encoded in the main clause. Following widespread assumptions (a.o. Reichenbach 1947, Cinque 1999, Demirdache and Uribe Etxebarria 2004, Sigurdsson 2016, etc.), temporal and modal values of the proposition are encoded on specialized TP-internal temporal/modal functional projections, e.g. RefT (reference time) and EvT (evaluation time). (21) is a schematic e crually that, as it stands, these values are NOT encoded at the $\mathrm{CP}$ level.

(21)

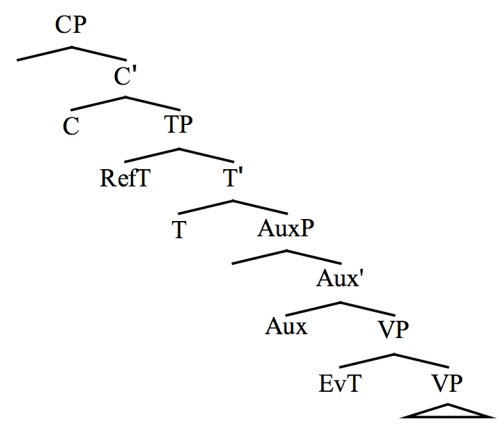

Consider now the interpretation of (22a), which is acceptable and in which the initial main clause external constituent is a central conditional. (22b) is an initial take on the representation of the interpretation of (22a), using the format in (20): the interpretation represented by (22b) is that the constituent in the specifier of FrameP, Adj-XP, should bind a TP-internal temporal or modal variable. I represent the intended reading by co-subscripting the temporal adjunct and the locus that encodes the Reference Time.

(22)

$$
\begin{aligned}
& \text { [Als ik klaar ben } \\
& \text { if I ready at de handout,] } \\
& \text { [cP [aan wie] moet ik } \mathrm{ik} \text { hem tonen?] } \\
& \text { to whom should I him show } \\
& \text { 'If my handout is ready, to whom should I show it?' }
\end{aligned}
$$

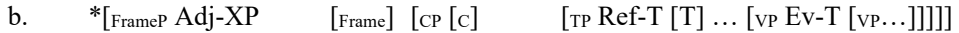

However, representation (22b) actually violates the locality condition postulated above because the temporal coordinates, Reference time (Ref-T) and Event time (Ev-T) in (21), are TP-internal and these layers do not have the strictly local relation to SpecFrameP that Haegeman and Greco and these layers do not have the strictly local relation to SpecFrameP that Haegeman and Greco
(2018) postulate as a condition on its interpretation, hence the *: the temporal coordinates are inaccessible for construal with Adj-XP. In the absence of the required local relation with the TPinaccessible for construal with Adj-XP. In the absence of the required local relation with the TP-
internal temporal coordinates, the clause-external central adverbial clause will not be able to internal temporal coordinates, the clause-external central adverbial clause will not be able to value the temporal relation of the main clause. However, (22a) is acceptable with the initial temporal adjunct successfully interpreted as a modifier of the main clause's temporal values. This means that there must be a way to derive the appropriate reading which is compatible with Haegeman and Greco's locality condition on the interpretation of the constituents in FrameP. The question arises then how this can be attained.

The proposal elaborated in Haegeman and Greco (2018) to account for the fact that (22a) is acceptable with the appropriate reading for the adverbial clause is that representation (22b) must be 'reconfigured' and that it must in fact be supplanted by a representation that does achieve the required locality relation. Put differently: there must be a representation in which the temporal features of TP are transmitted to $\mathrm{C}$ and can thus attain a local configuration with the constituent in FrameP. A natural proposal that comes to mind here is to explore the fact that (22a) is a case of an inverted V2 pattern in which the matrix finite verb moet ('must') has inverted with the subject $i k$ ('I'), and to propose that the required local configuration arises as the by-product of the movect (1) the finite $v$ b to the $\mathrm{C}$-d of 'indiry' chain ef the clause.

(22) c. [FrameP [als ik klaar ben met de handout] [Frame]

$$
\text { [CP [aan wie] [c moeti] [TP ik ... [Ti tmoet ] [vp ... taan wie]]]] }
$$

As must be clear, the same reasoning will also apply to (23a), in which the fronting of the direct object has led to subject-verb inversion. In (23b), the initial central adverbial attains a local relation with the temporal value of the finite verb in $\mathrm{C}$.

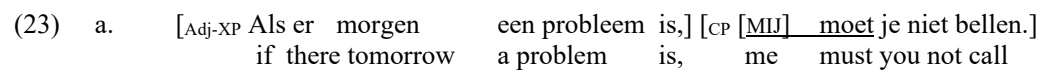

If there is a problem tomorrow, don't call me,

$$
\text { [CP [MIJ] [c moeti } \left.\left.\left.] \text { [TP je ...[Ti } \mathrm{t}_{\text {moet }}\right]\left[\mathrm{vp} \ldots \mathrm{t}_{\mathrm{mij}}\right] \mathrm{J}\right]\right]
$$

Recall from the discussion in Section 2.3 that while central adverbial clauses are interpretable as first constituents in a V3 configuration with non subject-initial V2 clauses, the situation in subjectinitial patterns is more complex. I turn to them in the next section.

4.2. Central adverbial clauses and subject-initial V2

There is an asymmetry in the compatibility of non subject-initial V2 clauses and subject-initial V2 clauses with V3 configurations with initial central adverbial clauses, as shown in Section 2. In the present section I address this asymmetry, which I will derive from the difference in the syntactic derivation of subject-initial V2 clauses and non subject-initial V2 clauses. First I briefly 
discuss the derivation of subject-initial V2 clauses and then I consider it in relation to the interpretation of the initial constituent located in the specifier of FrameP.

4.2.1. Subject-initial V2

Given that in a V3 configuration with an initial central adverbial clause, subject-initial V2 clause and non subject-initial V2 clauses pattern differently, it would appear that the so-called asymmetric approach to the derivation of verb second initiated by Travis (1984) and later adopted by, a.o. Zwart (1997a,b), and Mikkelsen (2015) is the more promising one. In this approach, inverted V2 patterns and non-inverted, i.e. subject-initial, V2 patterns have a different derivation, with the verb remaining in a lower position in the latter case.

Empirical support for the hypothesis that the verb remains lower in subject-initial V2 than in non subject-initial V2 comes from double agreement patterns in the East Netherlandic variety of Dutch (Zwart 1997: 140). (24) shows the agreement patterns for the first person plural. The dialect has two forms of agreement: $-e$ and $-t$. As can be seen in (24a), complementizer agreemen is realized as $-e$, the sentence-final finite verb in this example has the ending $-t$. In (24b), the verb occupies second position in a subject-initial V2 pattern; its agreement is realized as $t$, i.e. the same form as in (24a). In (24c), the finite verb has inverted with the subject and is marked by $-e$, ie, it shows the form of agreement displayed by the complementizer in (24a).

(24) a. datt-e wy speul-t/*e.

that-e we play-t/*e

'that we are playing'

b. Wy speul-t/*e.

we $\quad$ play-t/*e

Wo are playing.'

c. Woar speul-e/*t wy?

where play-e?*t we
'Where do we play?' (Zwart 1997: 140. (49) is his (73))

I focus on the core features of the asymmetric analysis here, and leave details of specific implementation as well as a cartographic revision of the proposal (Haegeman and Greco 2018) aside: the main idea is that inverted V2 patterns are derived by movement of the finite verb to the $\mathrm{CP}$ layer, as represented in (25a), while in the non-inverted subject-initial pattern, the subject remains in its canonical position (Spec,TP) and the finite verb occupies a TP-internal head, say $\mathrm{T}$ (25b). In terms of the derivations in (25), the generalization is then that when the verb remains in a TP-internal position, it is associated with the $-t$ ending, when it has moved to $\mathrm{C}$, it displays the $-e$ ending.

(25) a.

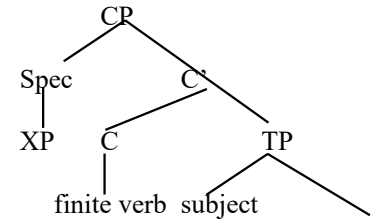

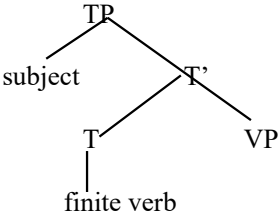

Two preliminary comments are to be made at this point. First, to rule out V2 transgressions with central adverbial clauses and subject-initial V2, one might propose that Frame selects CP an hence that (25b) simply cannot constitute the complement of Frame. However, this account would incorrectly rule out the acceptable combination of a peripheral adverbial clause with a subjectinitial V2 clause. These patterns are acceptable, as illustrated in (9d).

Representation (25b) also raises some independent issues. Observe that subject-initial V2 clauses are declaratives and function as assertions. If illocutionary force is encoded at the $\mathrm{CP}$ level, a subject-initial V2 clause represented as in (25b) would in fact lack the encoding of illocutionary force. This suggests that (25b) is not fully adequate with respect to the representations adopted here.

Potentially there is also a theory internal objection to adopting (25b) as the representation of subject-initial V2 clauses, at least with respect to certain assumptions. Under the recent reinterpection proposed that the Agre $(\varphi-)$ and Tense features associated with $\mathrm{C}$. if the fort property of $\mathrm{T}$, rather, they belong to $\mathrm{T}$. $\mathrm{p}$ hase' $\mathrm{C}$, $\mathrm{C}$. If the formal features of finite $T$ are taken to ori in $(26)$

The proposal adopted here is that while in subject-initial V2 clauses the finite verb does not move to C, and (25b) as such represents the TP layer of subject-initial V2 root clauses, it must be enhanced with a CP layer encoding illocutionary force dominating the TP layer hosting the subject-initial V2 configuration as in $(25 \mathrm{c}) .^{12,13}$

(25) c.

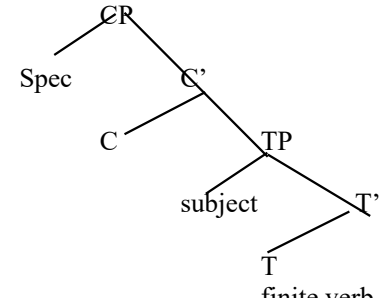

4.2.2. V2 transgressions and subject-initial V2

If we assume that the representation of StD subject-initial V2 clauses is as in (25c), (26b) below will correspond to the crucial parts of the representation of the unacceptable (26a). In this representation, in the absence of $\mathrm{V}$ to $\mathrm{C}$ movement, the local configuration required for the interpretation of FrameP is not attained. By hypothesis, the central adverbial clause in SpecFrameP does not have access to the TP-internal temporal and modal coordinates. ${ }^{14}$ As a 
result, the temporal adjunct in SpecFrameP cannot be interpreted as a temporal modifier of the event encoded TP-internally, as informally indicated by cosubscripting in (26b).

(26) a.

$$
\begin{array}{llllll}
\text { *[Als } & \text { mijn } & \text { tekst } & \text { morgen klaar is, } \\
\text { if } & \text { my } & \text { tekst } & \text { tomorrow ready is } \\
\text { ik } & \text { zal } & \text { je } & \text { hem opsturen. } \\
\text { I } & \text { will } & \text { you } & \text { him send }
\end{array}
$$

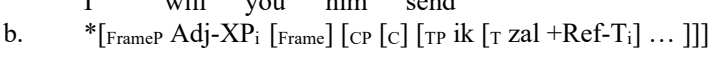

Recall that not all subject-initial V2 root clauses are incompatible with the V3 pattern with an initial central adverbial clause. As mentioned, such patterns are acceptable if the subject is information structurally distinguished, for instance in the form of having contrastive focus (27a) or being a $w h$-phrase (27b):

$$
\begin{aligned}
& \text { (27) a. [Als er morgen een probleem is, } \\
& \text { if there tomorrow a problem is } \\
& \begin{array}{lllll} 
& \text { zal ons niet helpen. } \\
\text { PIET } & \text { will us not help }
\end{array} \\
& \text { 'If there is a problem tomorrow, PIET won't help us.' } \\
& \text { b. }[\text { Als er morgen een probleem is, } \\
& \text { if there tomorrow a problem is } \\
& \text { [wie] gaat (er) ons helpen? } \\
& \text { who goes (there) us help }
\end{aligned}
$$

Following Mikkelsen (2015: 597, 628-9), I assume that in a subject-initial V2 pattern, an information structurally undistinguished subject remains TP-internally and the finite verb does not move to $\mathrm{C}$, as outlined above, while an information structurally distinguished subject moves to a position in the left periphery triggering verb movement to C. Support for V-movement to C with $w h$-subjects comes from the fact that for Flemish speakers $w h$-subjects require $e r$-insertion. If expletive er occupies the canonical subject position, then from (28) we conclude that the finite verb heeft ('has'), which occurs in a position to the left of the canonical subject position, must have moved to $\mathrm{C}$. I do not pursue this point here.

(28) Wie heeft er dat boek gelezen?

who has there that book read

'Who has read that book?'

4.3. Initial adverbial clauses in V2 transgressions

4.3.1. Speech act modifiers

The analysis straightforwardly predicts that conditionals acting as speech act modifiers, like those in (29), will be compatible with a subject-initial V2 clause in a V3 combination. ${ }^{15}$ Like relevane croposition expressed in the main clause, rather, they modify the temporality of CP i.e. the speech act. Thus, in contrast with unacceptable $\checkmark 3$ patterns in which the central adverbial clauses cannot be related to the TP-internal matrix temporal and modal values, central adverbial clauses which modify the speech act in (29) are directly construed with CP.
(29) a. Als ik eerlijk mag zijn,

$$
\begin{aligned}
& \text { if Ias gisteren ook al zo. } \\
& \text { dhat was yesterday also already like that } \\
& \text { 'To be honest, it was already like that yesterday.' } \\
& \text { b. Als het je interesseert, } \\
& \text { if it you interests } \\
& \text { ik heb gisteren Peter ontmoet } \\
& \text { I have yesterday Peter met } \\
& \text { 'If you are interested, I met Peter yesterday.' }
\end{aligned}
$$$$
\text { Als } \quad \text { ik } \quad \text { eerlijk mag } \text { zijn }
$$

4.3.2. Irrelevance conditionals and concessive free relatives

Recall that while in a $\mathrm{V} 3$ configuration, central adverbial clauses are not compatible with subject-initial V2 (30a), irrelevance conditionals are compatible with subject-initial V2: (18b) is repeated as $(30 \mathrm{~b})$ :

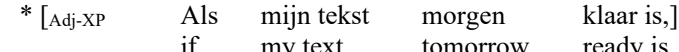

$$
\begin{aligned}
& \text { ik zal je hem opsturen. } \\
& \text { I } \quad \text { will you him opstu } \\
& \text { 'If my text is ready tomorrow, I will send it to you.' } \\
& \text { b. [Adj-XP Of mijn tekst morgen klaar is of niet, }
\end{aligned}
$$

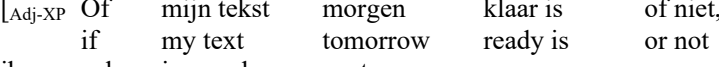

$$
\begin{aligned}
& \text { zal je hem opsturen. } \\
& \text { 'Whether my text is ready or not tomorrow, I will send it to you.' }
\end{aligned}
$$

In (30a), the truth value of the main assertion (CP) is conditional on Adj-XP: Adj-XP provides a value for a temporal/modal variable in the matrix $\mathrm{CP}$ and to do so it needs to be in a strictly local relation with the TP-internal variable. In the absence of $\mathrm{V}$ to $\mathrm{C}$ movement, this local relation is not available. In (30b), on the other hand, the truth value of the main assertion in the V 2 clause is not conditional on Adj-XP: the assertion in the V2 clause remains valid regardless of Adj-XP. This means that the looser relation between SpecFrameP and the V2 main proposition is sufficient: the adjunct clause does not need to provide a value for a TP-internal temporal or modal variable in the matrix clause. As a result, $\mathrm{V}$ to $\mathrm{C}$ movement is not required to derive the interpretation.

Along the same lines, concessive adverbial free relatives also are fully compatible with subject-initial V2 root declaratives with an information structurally undistinguished subject, as shown by (31a), which contrasts with the unacceptable (31b), in which a central adverbial clause combines with a subject-initial V2 root declarative with information structurally undistinguished subject:

(31) a

$$
\begin{array}{llll}
\text { a. } & \text { [Hoe hard je } & \text { ook werkt, }] \\
\text { how hard you } & \text { PART work } \\
\text { [je] haalt } & \text { het toch niet. } \\
\text { you succeed } & \text { it PART not } \\
\text { 'However had you work, you won't succeed. } \\
\text { b. }
\end{array}
$$

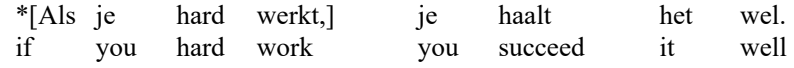


'If you work hard, you'll manage.'

As was the case with speech act modifiers in (29) and with irrelevance conditionals in (30b), the truth conditions of the matrix clause in (31a) are independent of those in the concessive free relative so that the initial constituent does not need to be related to the TP-internal temporal or modal coordinates.

\section{V2 transgressions and micro variation: West Flemish}

5.1. The data

5.1.1. V2 transgressions with subject-initial V2 root clauses

(32a) and (32b), in which a central adverbial clause combines with a subject-initial V2 clause, are accepted by some (West) Flemish (WF) speakers. The pattern is attested in WF and has been documented and discussed in the descriptive literature (see Lybaert et al to appear, and Vercouillie 1885, Debrabandere 1976, Vanacker 1977, Devos and Vandekerckhove 2005, Saelens 2014). ${ }^{16}$ The StD analogues are unacceptable, as shown by (12a), repeated in (32c).

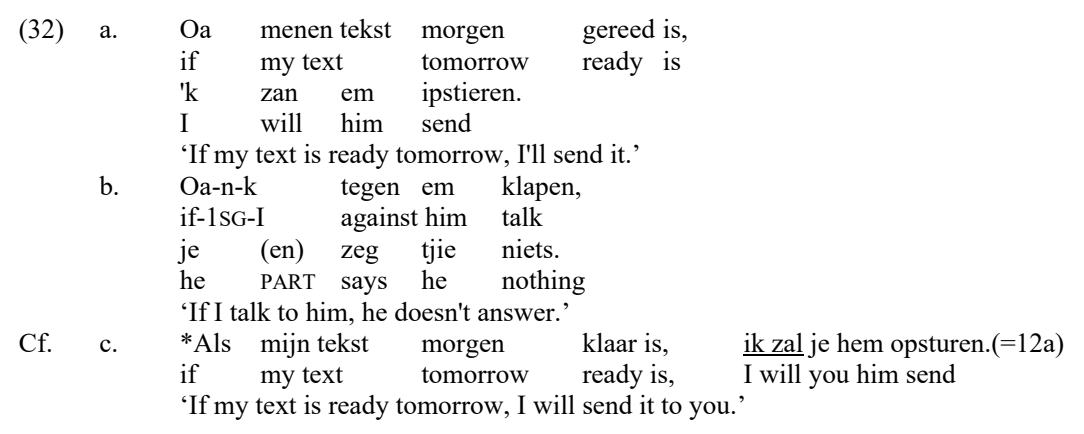

In WF, the non-inverted pattern always alternates with regular $\mathrm{V} 2^{17}$, as shown in (33):

(33) a. Oa menen tekst morgen gereed is, if my text tomorrow ready is zan-k em ipstieren.

will-I him send

b. Oa-n-k tegen em I'll send it.'
if-1SG-I against him talk
(en) zegt je niets.
PART says he nothing

'If I talk to him he doesn't answer.'

5.1.2. WF non-inverted V3 as a framing device

The non-inverted V3 pattern is typically used in oral narrative contexts. Contemporary attestations are provided in (34)

Om wieder $\quad \begin{aligned} & \text { een feestie } \\ & \text { geven by ons thus, } \\ & \text { if-1PL we }\end{aligned}$ a party
m'en altive at our house
we-have aver.
'If we give a party at our place, we always have leftovers.

(Dominique Persoone ('Bruges), TV-chef, Njam, 15 June 2016)

b. Als je tegen dienen gast klapt,

if you against that guy talk

je merkt dat gewoon

you notice that simply

'If you talk to that guy, you simply notice.'

(overheard on the train, 19 November 2016, male speaker, 25-30)

c. Je moet overal opnieuw erbeginnen.

he has everywhere again start afresh

'He has to start from zero every time.'

Ot'n in China komt, je kent der geen bal van.

'If he goes to China, he doesn't have a clue.'

(overheard in waiting room hospital, AZ St Jan, 12 December 2016, male speaker 50-60)

d. En ame em zien ankommen, zegt ze

$\begin{array}{lll}\text { and if-1PL-we him } & \begin{array}{l}\text { zien ankommen, } \\ \text { see arrive, }\end{array} & \text { zegt ze } \\ \text { says she, }\end{array}$

Pierse valt dat seentive,

Pierre vult dat ton in
Pierre fills that then PART

'And if we see him [the ticket collector] arrive, she says, Pierre fills out the rail card,

(overheard on the train, 3 June 2018, female speaker, 40-50)

Non-inverted V3 patterns create an effect of heightened 'immediacy': the pattern puts speaker/hearer in medias res and tends to be used in contexts with high speaker involvement. Haegeman and Greco (2018) assume that the initial constituent in such non-inverted V3 patterns occupies the specifier of FrameP. In narrative contexts (35a), its role is to move the narrative forward by providing a new frame to which the main proposition is related. It can also be used to characterize a subject by a range of properties and the V3 patterns with subject-initial V2 is used to go through each of them (35b). The use of the V3 pattern may also create an effect of heightened suspense and the use of a V3 pattern with non-inverted V2 root clause may contribute to creating an effect of surprise $(35 \mathrm{c})$.

(35)

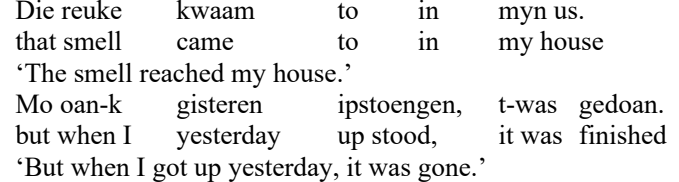

Dat is toch een roare:

"She's a strange person:"

Oa-j eur vroagt, ze komt niet.

if you her invite, she comes not 
'If you invite her, she doesn't come.'

Oa-j eur nie vroagt, $\mathrm{z}$ 'is dul.

if you her not invite, she-is angry

'If you don't invite her, she gets angry.'

tuskwamen,

when-we home came

de voordeure stond open en de lucht was an.

he front door stood open and the light was on

'When we came home, the front door was open and the light was on!'

5.2. Non-inverted V3: micro variation in the derivation of subject-initial V2

In the initial debate concerning the derivation of subject-initial V2, the literature tacitly converged on the hypothesis that V2 languages presented a unified picture, i.e. that if the asymmetric derivation was shown to suit one language, it was generalized to apply across all V2 patterns an V2 languages. Observe, though, that the nature of the argumentation deployed at the time already suggested that a unified view need not be optimal, in that the evidence for one derivation or the other originated with different varieties of V2 languages. Zwart's (1997a,b) empirical support of the asymmetric view of Dutch as in (25) mainly invokes evidence from Dutch dialects (see (24)); in contrast, in support of the alternative symmetric view, Craenenbroeck and Haegeman (2007) mainly invoke Flemish data. One piece of evidence concerns the distribution of the Flemish

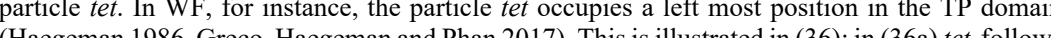
(He com the complementizer dat ('th') and precedes Valere, the subject of the finite clause, in (36b) it here Valère.

$$
\begin{aligned}
& \text { a. Kpeinzen dat tet Valère da nie goa willen doen } \\
& \text { I.think that tet Valère that not } \\
& \text { 'I think that Valère won't want to do that.' } \\
& \text { me tet Valèn do no to zeggen } \\
& \text { with tet Valère that not to say } \\
& \text { 'Valère not having said that' }
\end{aligned}
$$

\begin{tabular}{|c|c|c|c|c|c|c|c|}
\hline \multirow{2}{*}{\multicolumn{2}{|c|}{ 37) }} & $\begin{array}{l}\text { Morgen } \\
\text { tomorrow }\end{array}$ & $\begin{array}{l}\text { goa } \\
\text { goes }\end{array}$ & $\begin{array}{l}\text { tet } \\
\text { tet }\end{array}$ & $\begin{array}{l}\text { Valère da } \\
\text { Valère that }\end{array}$ & $\begin{array}{l}\text { niet } \\
\text { not }\end{array}$ & $\begin{array}{l}\text { willen doen. } \\
\text { want do }\end{array}$ \\
\hline & & \multicolumn{6}{|c|}{ 'Valère won't want to do that tomorrow.' } \\
\hline & b. & $\begin{array}{l}\text { Valère goa } \\
\text { Valère goes }\end{array}$ & $\frac{\text { tet }}{\text { tet }}$ & $\begin{array}{l}\text { da } \\
\text { that }\end{array}$ & $\begin{array}{l}\text { morgen } \\
\text { tomorrow }\end{array}$ & $\begin{array}{l}\text { nie } \\
\text { not }\end{array}$ & $\begin{array}{l}\text { willen doe } \\
\text { want do }\end{array}$ \\
\hline
\end{tabular}

As can be seen in (37), in root clauses tet invariably follows the finite verb, both in non subjectinitial V2 (37a) and in subject-initial V2 (37b). Craenenbroeck and Haegeman (1997) construe this as evidence that in (37a), as well as in (37b), the finite verb has exited the TP area.

Postma (2011) raises the hypothesis that subject-initial V2 is not unified across the Germanic languages and his proposal, though with a different implementation, is taken up in Haegeman and Greco (2018). These authors propose that there is micro variation in the derivation of subjectinitial V2 across varieties of Dutch. For StD, it is proposed that the finite verb does not move to $C$ (38a); for WF they propose that the finite verb does move to C (38b).

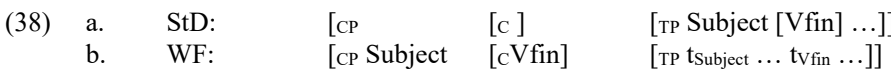

The immediate prediction of this differentiation in the derivation of subject-initial V2 is that a StD $\mathrm{V} 3$ configuration in which a central adverbial clause combines with a subject-initial root clause is unacceptable $(38 \mathrm{c})$, but that the same pattern will be acceptable in WF, where by virtue of $\mathrm{V}$-movement to $\mathrm{C}$, the initial adverbial clause attains access to the temporal and modal values encoded in the verbal domain (38d):
(38) c

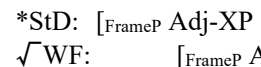
[c]
[
ik $[\mathrm{zal}] \ldots]]]$

As also demonstrated in Haegeman and Greco (2018), an initial adjunct in a regular V2 root clause can be reconstructed to a clause-internal position. In contrast, the initial adverbial constituent in the non-inverted V3 pattern cannot be so reconstructed. I provide one set of data to illustrate this point. In a regular V2 pattern, the initial central adverbial clause can be interpreted as modifying either the matrix event time (i.e. in (39a), 'the claim was made when it was ready') or the event time of the embedded clause (i.e. in (39a) 'she will make a call if it is ready'). These interpretations the with a subject-initial V2 clause (39b), the embedded construat in adverbial clause can only be interpreted as modifying the matrix time. ${ }^{18}$

(39) a. Oa-t gereed was, zei ze da ze ging bellen. if-it ready was said she that she would call 'She said that she would call if it was ready.'

b. Oa-t gereed was, ze zei da ze ging bellen. if-it ready was she said that she would call

These data confirm that the status of the initial adjunct in a V3 configuration differs from that in the V2 configuration and they are in line with Broekhuis and Corver's (2016) proposal that V3 patterns arise due to the presence of main clause external constituents.

\section{Summary}

This chapter focusses on the availability of central adverbial clauses as initial constituents in V2 transgressions, i.e. patterns in V2 languages in which the finite verb is preceded by two constituents, thus leading to a V3 pattern. If the initial constituents in these V3 configurations are analyzed as main clause external constituents (Broekhuis and Corver 2016), the prediction would be that central adverbial clauses should be excluded from this position. At first sight, the prediction seems correct: the judgement in $(40)$ is for $\mathrm{StD}$. In this example, a central adverbial clause is merged with a fully-fledged V2 root clause and the central adverbial clause would have to be taken to occupy the main clause external slot. Its clause external position entails that the adverbial clause will not be (sufficiently) syntactically integrated to provide the temporal or modal values for the will not be (sufficiently)

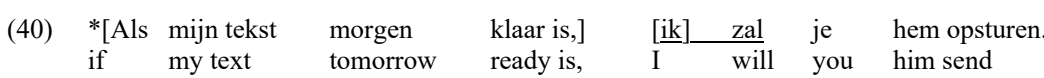


However, one problem for the prediction is that in WF, itself a bona fide $\mathrm{V} 2$ language, the analogue f $(40)$ is accepte. In addition, even in StD the prediction is not fully borne out. In several V3 contexts, one of which is illusted in (41), the initil centrat adverbial clate modifies the temporal or modal values of the associated clause, but despite this, it appears in what seems to be a main clause external position (in the sense of Broekhuis and Corver 2016):

(41) $[$ Als mijn tekst klaar is,

$$
\begin{aligned}
& \text { if my text ready is } \\
& \text { [aan wie] moet ik hem opsturen? } \\
& \text { to whom should I him send } \\
& \text { 'If my text is ready, to whom shall I send it?' }
\end{aligned}
$$

I have argued that the crucial distinction between (40) and (41) is that the root clause in (40) is a subject-initial V2 clause, while that in (41) is non subject-initial V2. These data thus suggest that in StD the internal syntax of the V2 clause determines the possible syntactic integration of the central adverbial clause in the main clause external position. Or, to put it differently, that properties of narrow syntax are relevant at the level of discourse interpretation.

\section{References}

Astruc-Aguilera, Lluisa. 2005. The form and function of extra-sentential elements. Cambridge Occasional Papers in Linguistics 2: 1-25.

Auer, Peter. 1996. The pre-front field in spoken German and its relevance as a grammaticalization position. Pragmatics 6: 295-322

Austin, J. L. (1956) Ifs and cans. Proceedings of the British Academy 42: 109-132.

Auwera, Johan van der. 1986. Conditionals and speech acts. In On Conditionals, Elisabeth Traugott, et al (eds.). 197-214. Cambridge: Cambridge University Press.

Banfield, Ann (1982) Unspeakable Sentences. Oxford: Routledge.

Bhatt, Rajesh, and Roumyana Pancheva. 2006. Conditionals. In The Blackwell Companion to Syntax Martin Everaert and Henk van Riemsdijk (eds.), Vol. I, 638-687. Malden Blackwell.

Biberauer Theresa and Ian Roberts. 2014. Rethinking formal hierarchies: A proposed unification. Cambridge Occasional Papers in Linguistics 7: 1-35.

Boogaert, Ronny. 2007. Conditionele constructies met moest(en) en mocht(en) in BelgischNederlands en Nederlands Nederlands. Neerlandistiek.Nl: 07.05

Broekhuis, Hans and Norbert Corver. 2016. Dutch Syntax. Verbs and Verb Phrases. Volume 3 : Chapter 14: main clause external elements. http://www.oapen.org/

Catasso, Nicholas. 2015. On Postinitial Aber and other syntactic transgressions: Some considerations on the nature of V2 in German, Journal of Germanic Linguistics 27: 317 365 .

Chomsky, Noam. 2008. On phases. In Foundational Issues in Linguistic Theory: Essays in Honor of Jean-Roger Vergnaud, Robert Freidin, Carlos P. Otero, and Maria Luisa Zubizarreta (eds.).

Cinque, Gulgielmo. 1999. Adverbs and Functional Heads. New York: Oxford University Press. Cinque, Guglielmo. 2008. Two types of non-restrictive relatives. In Empirical Issues in Syntax and Semantics 7, Olivier Bonami and Patricia Cabredo Hofherr (eds.), 99-137. Paris: CNRS.

Comrie, B. 1986. Conditionals: A typology. In On Conditionals, Elisabeth C. Traugott, Alice te Meulen, Judy Snitzer Reilly, and Charles A. Ferguson (Eds.), 77-102. Cambridge: Cambridge University Press.

Craenenbroeck, Jeroen van and Liliane Haegeman. 2007. The Derivation of subject-initial V2. Linguistic Inquiry 38: 167-178.
D'Avis, Franz Josef. 2004. In front of the prefield - inside or outside the clause? In The Syntax and Semantics of the Left Periphery, Horst Lohnstein \& Susanne Trissler (eds), 139-177. Berlin: Mouton de Gruyter.

Debrabandere, Frans. 1976. De SVf-volgorde in zinnen met een aanloop.' In Handelingen van de Koninklijke Commissie voor Toponomie en Dialectologie. Tongeren: G. Michiels. 87-97.

Demirdache, Hamida and Myriam Uribe-Etxebarria. 2004. The syntax of time adverbs. In The Syntax of Time, Jacqueline Guéron and Jacqueline Lecarme (eds.), 143-180. Cambridge,

Demske, Ulrike. 2015. Adverbials and the left periphery: Syntax and Information Structure in the History of German. DIGS abstract.

Devos, Magda and Reinhilde Vandekerckhove. 2005. Westvlaams. Tielt: Lannoo.

Donaldson, Bryan 2012. Initial subordinate clauses in Old French: Syntactic variation and the clausal left periphery. Lingua 122: 1021-1046.

Ducrot, Oswald. 1983. Le Sens Commun. Le Dire et le Dit. Paris : les Editions de Minuit.

Elhadad, Michael and Kathleen R. McKeown. 1990. Generating connectives. Proceedings of Coling 90, vol 3. 97-101.

Emonds, Joe. 2004. Unspecified categories as the key to root constructions. In Peripheries, David Adger, Cécile DeCat and Georges Tsoulas (eds.), 75-121. Dordrecht: Kluwer.

Endo, Yoshio and Liliane Haegeman. 2014. Adverbial concord: merging adverbial clauses. MIT Working papers in linguistics: 73. Proceedings of FAJL. Shigeto Kawahara and Mika Igarashi (eds.), 25-44.

Frascarelli, Mara. 2016. Dislocations and framings. Ms. Università Roma Tre.

Frey, Werner. 2012. Peripheral adverbial clauses, their licensing and the prefield in German. In Satzverknüpfung - Zur Interaktion von Form, Bedeutung und Diskursfunktion, Eva Breindl, Gisella Ferraresi and Anna Volodina (eds.), 41-77. Berlin: de Gruyter.

Frey, Werner and Liliane Haegeman (in progress). Adverbial clauses. Leibniz-ZAS and UGhent.

Giorgi, Alessandra. 2014. Prosodic signals as syntactic formatives in the left periphery. In $O n$ Peripheries, Exploring Clause initial and Clause final Positions, A. Cardinaletti, G. Cinque and Y. Endo (eds.), 161-188. Tokyo: Hituzi Syobe Publishing.

Greco, Ciro and Liliane Haegeman. 2016. Frame setters and the macro variation of subject-initia V2. lingbuzz/003226

Greco, Ciro, Liliane Haegeman and Trang Phan. 2017. Expletives and Speaker-related Meaning. In Order and Structure in Syntax II: Subjecthood and Argument Structure, ed. Michelle Sheehan and Laura Bailey, 69-93. Berlin: Language Science Press.

Griffiths, James. \& Mark de Vries. 2013. The syntactic integration of appositives: evidence from fragments and ellipsis. Linguistic Inquiry 44: 332-344.

Haegeman, Liliane. 1991. Parenthetical adverbials: the radical orphanage approach. In Aspects of Modern Linguistics. S. Chiba et al (eds.), 232-254. Tokyo: Kaitakushi Press.

Haegeman, Liliane. 1996. Verb second, the split CP and null subjects in early Dutch finit clauses. GenGenP. Available on: http://ling.auf.net/lingBuzz/001059

Haegeman, Liliane. 2002. Anchoring to the speaker, adverbial clauses and the structure of CP. Georgetown University Working Papers in Theoretical Linguistics 2: 117-180.

Haegeman, Liliane. 2003. Conditional Clauses: External and Internal Syntax. Mind \& Language 18: $317-339$.

Haegeman, Liliane. 2004. The syntax of adverbial clauses and its consequences for topicalisation. Antwerp Papers in Linguistics. 107. Current Studies in Comparative Romance Linguistics: 61-90.

Haegeman, Liliane. 2006. Conditionals, factives and the left periphery. Lingua 116: 1651-1669. Haegeman, Liliane. 2009. Parenthetical adverbials: the radical orphanage approach. In Dislocated Elements in Discourse : Syntactic, Semantic and Pragmatic Perspectives. 
Shaer Benjamin, Cook Philippa, Frey Werner and Maienborn Claudia (eds.), 331-347. London: Routledge. Reprinted from Haegeman (1991).

Haegeman, Liliane. 2012. Adverbial Clauses, Main Clause Phenomena and the Composition of the Left Periphery. Oxford: Oxford University Press.

Haegeman, Liliane and Yoshio Endo. 2017. Adverbial clauses and adverbial concord. Ms. DiaLing. Under review.

Haegeman, Liliane, and Ciro Greco. 2018. West Flemish V3 and the interaction of syntax and discourse. Journal of Comparative Germanic Linguistics 21: 1-56.

Haegeman, Liliane, Benjamin Shaer and Werner Frey. 2009. Postscript: problems and solution for orphan analyses. In Dislocated Elements in Discourse: Syntactic, Semantic and Pragmatic Perspectives. Shaer Benjamin, Cook Philippa, Frey Werner and Maienborn Claudia (eds.), 348-365. London: Routledge.

Haspelmath, Martin and Ekkehard König. 1998. Concessive Conditionals in the languages of Europe. In Adverbial Constructions in the Languages of Europe. Johan van der Auwera (ed.), in collaboration with D.P.O Baoill, 563-640. Berlin/New York: Mouton de Gruyter.

Holmberg, Anders. 2015. Verb second. In Syntax. An International Handbook of Contemporary Syntactic Research. $2^{\text {nd }}$ edition, Tibor Kiss and Artemis Alexiadou (eds), 343-384. HSK Series. Berlin: Walter de Gruyter Verlag.

Hornstein, Norbert. 1993. As Time Goes By: Tense and Universal Grammar. Cambridge, Mass. MIT Press.

Huddleston, Rodney. 1984. Introduction to the Grammar of English. Cambridge, UK Cambridge University Press.

Iatridou, Sabine. 1994. On the contribution of conditional then. Natural Language Semantics: 171199.

Kearns, John. 2006. Conditional assertion, denial, and supposition as illocutionary acts. Linguistics and Philosophy 29: 455-485.

. Clause Combining in Grammar and Discourse. John Haiman and Sandra Thomson (eds). 101-133. Amsterdam: Benjamins.

Koster, Jan. 2000. Extraposition as parallel construal. Ms, University of Groningen.

Lybaert, Chloé, Bernard De Clerck, Jorien Saelens and Ludovic Decuypere. In press. A corpusbased analysis of V2 variation in West Flemish and French Flemish dialects. Journal of Germanic Linguistics.

Mikkelsen, Line. 2015. VP anaphora and verb-second order in Danish. Journal of Linguistics 51: $595-643$

Postma, Gertjan. 2011. Modifying the hearer. The nature of the left periphery of main clauses in Frisian and Dutch. Paper presented at $C G S W$ 26, Meertens Institute, Amsterdam, the Netherlands, June 23-24.

Quirk, Randolph, Sidney Greenbaum, Geoffrey Leech, Jan Svartvik. 1985. A Comprehensive Grammar of the English Language. London: Longman.

Reichenbach, Hans. 1947. Symbolic Logic. Berkeley: University of California.

Reis, Marga. 1997. Zum syntaktischen Status unselbständiger Verbzweit-Sätze. In Sprache im Fokus. Festschrift für Heinz Vater zum 65. Geburtstag. Christa Dürscheid, Karl-Heinz Ramers, and Monika Schwarz (eds.), 121-144. Tübingen: Niemeyer.

Rizzi, Luigi. 1997. The fine structure of the left periphery. In Elements of Grammar, Liliane Haegeman (ed.), 281-337. Dordrecht: Springer.

Saelens, Jorien. 2014. Topicalisering zonder inversie: een ingveonisme? Master paper, Ghen University.

Salvesen, Christina. 2017. Resumptive particles and V2. Ms.
Schwartz Bonnie and Sten Vikner. 1996. The verb always leaves IP in V2 clauses. In Parameters and Functional Heads, Adriana Belletti and Luigi Rizzi (eds.), 11-62. Oxford: Oxford University Press.

Sigurdsson, Halldor. 2016. The Split T analysis. In Finiteness Matters: on Finiteness related Phenomena in Natural Languages, Kristin Eide (ed.), 79-92. Amsterdam: John Benjamins. Skårup, Povl. 1975. Les premières zones de la proposition en ancient français. Revue Romane, special issue 6.

Travis, Lisa. 1984. Parameters and effects of word order variation. Doctoral dissertation, MIT, Cambridge, Mass.

Vanacker, Valère .F. 1977. Syntactische overeenkomsten tusen Frans-Vlaamse en Westvlaams dialekten. In De Franse Nederlanden. Les Pays-Bas Francais. Jaarboek. Rekkem: On Erfdeel, bzw. 206-216.

Vercouillie, Jozef. 1885. Spraakleer van het Westvlaamsch Dialect. Onze Volkstaal 2: 3-47. Vries, Mark de. 2009. The left and right periphery in Dutch. The Linguistic Review 26: 291-327. Williams, Edwin, 1977. Discourse and Logical Form. Linguistic Inquiry 8:101-139.

Wolfe, Sam. 2016. On the left periphery of V2 languages. Selected Papers from the 41st Incontro di Grammatica Generativa. Rivista di Grammatica Generativa 38: 287-310.

Zwart, Jan-Wouter. 1997a. The Germanic SOV languages and the universal base hypothesis. In The New Comparative Syntax, Liliane Haegeman (ed.), 246-264. London: Addison-Wesley.

Zwart, Jan-Wouter. 1997b. Morphosyntax of Verb Movement: A Minimalist Approach to the Syntax of Dutch. Dordrecht: Kluwer.

Zwart, Jan-Wouter 2005. Verb second as a function of Merge. In The Function of Function Words and Functional Categories, Marcel den Dikken and Cristina M Tortora (eds), 11-40. Amsterdam: John Benjamins.

This research was conducted as joint work with Ciro Greco and presented at DGfS 2017, in the Worksho AG2 Information structuring in discourse, at the Universität des Saarlandes, Saarbrücken, as well as at

I thank the audiences for their comments. Special thanks go to Werner Frey, Terje Lohndal,

Andrew Radford, and Sten Vikner, for comments on various versions of this work.
The research was funded by FWO project 2009-Odysseus-Haegeman-G091409.

The same contrast obtains for German, as shown by (i).
$\begin{array}{lll}\text { (i) } * \text { Wenn es regnet, }] & \text { [ich] gehe spazieren }\end{array}$

when it rains,

'If it rains,

The conjunction als ('if') often corresponds either to if or to when, i.e. with a conditional or future temporal with cases such as relevance were available I have opted for the conditional reading, to maximize similarity where the two readings are available the judgements do not differ if the conditional reading is replaced by a

temporal reading.
Anticipating the discussion in Section 5 , the West Flemish analogues for the examples discussed in this section show the same patterns as their Standard Dutch counterparts.

udgements, based on an informal questionnaire, were obtained from 10 speakers, 7 originating from the Netherlands and 3 from Belgium.

(4) further study.

Thanks to Fred Weerman for bringing these data to my attention.
$\begin{array}{ll}\% \text { Als } & \text { er } \\ \text { if } & \text { there }\end{array}$
morgen
een probleem is, wie zal er ons helpen?

"If there is a problem tomorrow, who will help us? 


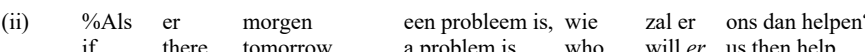
'If there is a problem tomorrow, who will help us?'

For completeness' sake, it should be pointed out that $e$-insertion was also preferred by Flemish speaker who do not accept V3 patterns with subject-initial adverbial clauses. The distribution of $e$-insertion

requires further study.
The preverbal zone is also called 'fondement', i.e. 'foundation'.

The slot labelled 'Extraposition' is a position "outside the clause proper ('hors de la proposition", p. 179)

The absence of low construal is documented in more detail in Greco and Haegeman (2016) and Haegeman and Greco (2018).

The construct FrameP being, by hypothesis, 'outside the narrow syntax', one might conceive of the generalized strict locality requirement governing its interpretation as constraining the building of discourse relations. Concomitant with this position, one might speculate that the syntactic relations such as Probe and Agree canto aply ant on the nature of his discouse projection HP, Cingue (2008) writes:

In the spirit of Williams (1977), we must also assume that the 'Discourse Grammar' head H, as is the general rule for sentences in a discourse, blocks every 'Sentence Grammar' relation between its specifier and complement (internal Merge, Agree, Binding, etc.), despite the asymmetric ccommand relation existing between the two under the extension of the LCA to Discourse

I assume thammar (Cinque 2008: 199)

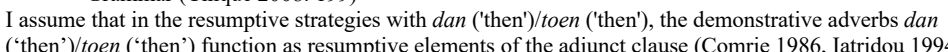
('then') Itoen ('then') function as resumptive elements of the adjunct clause (Comrie 1986, Iatridou 1994,
Bhatt and Pancheva 2006). A full analysis of the role of dan, though relevant, would take me too far As it stands (25c) makes subject-initial V2 similar to a regular subject-initial root clause in English or in French.

The asymmetric analysis can (and should) be recast in a cartographic approach according to which for instances, non-inverted V2 is derived by V-movement to Fin and inverted V2 implicates a higher projection. See Greco and Haegeman (2016), who follow Poletto (2013), Biberauer and Roberts (2014),

a cartographic approach, asymmetric V2 may be derived by the finite verb moving either to Fin (subject-initial V2 patterns) or to Force (inverted V2 patterns). This means that in asymmetric language Haegeman (2016) and Haegeman and Greco (2018) and the papers cited. Purely for expository reasons, I use the simpler representation here.

13 In contrast to the asymmetric approach to V2, Schwartz and Vikner (1996), and Craenenbroeck and Haegeman (2007) argue that in subject-initial $\mathrm{V}$, the verb also moves to C, i.e. that representation (25a) captures all V2 sentences. In a cartographic approach, the asymmetric approach can be reconciled with the proposal that the verb always leaves and Haegeman and Greco (2018).

Various ine condition can, for instance, be rephised in terms of phases and phase boundaries.

For some discussion see also Haegeman (2012: 181-82).
As can be observed, most examples cited here have a pronominal subject in the V2 clause, but this is not obligatory as shown by the attested (34d) and the constructed (35c). Saelens (2014) shows that non-inverte
V3 is compatible with nominal and with pronominal subjects. For the 1960 corpus they consulted, Saelens (2014) and Lybaert et al. (in press) show that the DP vs. pronoun contrast is not statistically significant. We refer to their work for details.

17 The opposite does not hold, cf. Section 5.3 and Greco and Haegeman (2018) and Haegeman and Greco (2018)

In this respect, the pattern differs from so-called hanging-topic left dislocation (HTLD) which allows construal in embedded domains. This suggests that an analysis adopting a null resumptive (e.g. dan 'then') is not adequate. Thanks to Hubert Truckenbrodt for bringing up this point. 